SCJR 16, no. 1 (2021): 1-4

\title{
Philip A. Cunningham, Ruth Langer, and Jesper Svartvik, Eds. Enabling Dialogue about the Land: A Resource Book for Jews and Christians
}

(Mahwah, NJ: Paulist Press, 2020), xviii + 419 pp.

\author{
EUGENE KORN \\ ebkorn@gmail.com \\ Center for Jewish-Christian Understanding and Cooperation in Israel, \\ Jerusalem 9339082
}

The authors of Enabling Dialogue about the Land state that their purpose is to provide resources for "constructive Jewish-Christian dialogue about Israeli-Palestinian issues" ( $\mathrm{x}$ ), and it offers theological, academic, and practical material toward this end. The book stresses the necessity for Christians and Jews, and Israelis and Palestinians, to understand each other, and it promotes the need to listen to, and not to deny, the views of others in this dialogue. While some of the essays could deal more thoroughly with how others view themselves, most of the authors strive mightily to acknowledge and squarely come to grips with diverse views of the conflict.

The book emerged from an International Council of Christians and Jews (ICCJ) project "Promise, Land and Hope" conducted between 2011-2016 by wellknown Christian and Jewish interfaith scholars. The volume itself covers a wide swath, as is evident from its format. Part I contains topical essays subdivided into "Scriptural Overviews," "The Meaning of the Land [in Jewish, Christian-Palestinian, and Muslim thought]," "Challenges," "Personal Reflections," and "Creative Approaches to the Land in Christian Theology." Part II offers a curriculum and guidelines for dialogue about Israel-Palestine. The book is thus a rich reservoir of scholarship, theology, personal narrative, and practical steps to advance a productive approach to this contentious and bedeviling subject.

Tamara Cohn Eskenazi, Michael Trainor, and J. Cornelis de Vos discuss references to the Land in the Hebrew Bible and the New Testament. Ruth Langer ably offers a schematic overview of Jewish theological views of the Land and the State of Israel. While a few $19^{\text {th }}$ century Jewish Reform thinkers denied Jewish peoplehood and did not hope for a restoration of a Jewish state on the Land, Langer notes that these ideas never took root. What sustained the overwhelming majority of European Jews and Jews in Arab Lands ("edot ha-mizrach") was the age-old yearning 
to return to Zion. Even contemporary ultra-Orthodox anti-Zionists fervently insist on the Jewish connection and return to the Land, rejecting only the political entity of Israel as the proper means for that return.

Jamal Khader, the only native Palestinian representative in the book, offers his Palestinian-Christian theology of the Land. His essay is an example of hard supersessionism. For him, Christians are the indigenous people of the Land, and in his spiritual reading of the Bible it is Christians who have Abraham, Isaac, and Jacob as forefathers and who are the subjects of the biblical drama. He writes, "We [Christians] were in Egypt, we came to the promised Land" (68). In his view, Christians are the heirs to the covenantal promises that continue through Jesus Christ. After Jesus, Christians are the people of God, and his theology separates Judaism and the Jewish people after Jesus from the Bible and biblical history.

Deborah Weissman and David Neuhaus offer important personal reflections on life in the Land today, reminding us that the subject is for many not academic or theoretical but connected to a deeply human reality. For Weissman, Jewish sovereignty in Israel is rebirth and cause for spiritual and political celebration, while Neuhaus, a Jesuit, stresses how wounded Palestinians and Israelis are from the perpetual conflict and its debilitating spiritual consequences.

Peter Petit calls our attention to the complexity of the subject. He details how Jews, Israelis, Christians, and Palestinians all bring a bewildering and often conflicting assortment of biblical, theological, and historical assumptions to the terrain. These diverse views influence both our emotional and cognitive stances when confronting the theology of the Land. As he puts it, "It's not a walk in the park" (129).

Ilan Troen provides a scholarly analysis of the roles of theology and history in claims to Palestine / Israel, observing that there is usually an intertwining of religious, historical, and political claims about the Land even in secularist ideologies. $\mathrm{He}$ also calls our attention to secularized versions of replacement theology, like the historical revisionism popularized by George Antonius and Edward Said-constructions that erase Jewish peoplehood and past Jewish links to the Land. Like hard supersessionism, these claims are assertions of faith, not "demonstrable fact[s]" (121). Finally, he notes how the idea of a native people morphed into the idea of an indigenous people to defy the authority of the modern state - in our case, Israel. This persists in spite of the fact that signatories to the 2007 UN Declaration of Rights stipulated that indigenous rights do not have priority over those of a sovereign state" (121).

Perhaps the most fertile part of the book is the section "Creative Approaches to Christian Theology." Its essays offer substantive recommendations for how Christian thinking about the Land can cultivate greater understanding and respect while recognizing essential religious, social, political, and historical realities of both Israelis and Palestinians.

The Swedish Lutheran biblical theologian Jesper Svartvik describes how current Christian theology is polarized between lingering supersessionism and Western Christian rejection of it. Shunning the non-possumus dead-end of old Christian theology regarding Jewish rights to the Land, he urges Christians to take 
seriously the biblical land promises as well as parenesis, meaning the moral obligations that the Bible places on Jews living on the Land. Neither the promises or paranesis can come at the expense of the other. Legitimate critique of Israel must be measured rather than "a ritualized condemnation of the State" (244). Both sides must listen to the other's story-primarily the persecution that was the Jewish fate outside the Land, as well as the Palestinian Naqba - and explore formative narratives, radical otherness, and trust-building endeavors in order to pave the way for healing and understanding.

John Pawlikowski also contributes a critically important essay in this section. After surveying the history of Christian theology of the Land, he limns a "theology of belonging" for Christians, Jews, and Muslims (262). This theology includes selfanalysis, acknowledging indigenous peoplehood, admitting the centrality of the Land tradition, developing positive attitudes and hospitality toward the Land's minorities, and "bonding with the earth," that is, taking physical land seriously rather than waiting for an eschatological release into a higher, heavenly realm (278).

Barbara U. Meyer probes alternatives to Christian post-Shoah religious thinking and current Palestinian theologies. Seeing that supersessionism is neither true nor good theology, she addresses the political and scriptural clash between postsupersessionist and Palestinian theologians, analyzing the conflict's cultural and spiritual implications. She too strives to overcome supersessionism and emerge with "a theology of belonging" (283).

Philip Cunningham discusses contemporary Catholic theological and biblical principles as manifested in Nostra Aetate and post-conciliar documents. These declarations present Judaism not simply as a religion but as "a fundamental unity of faith, land and people" (306). They acknowledge Jewish covenantal life, respect Jewish self-understanding, and are committed to human rights of all persons. Conceiving of Jews and Christians as "co-covenantal companions," Cunningham asks, "How might a Catholic theology of Jewish covenantal attachment to the Land be constructed?" (315). Remarkably, he also asks, "Could Jewish covenantal attachment to the Land have sacramental character for Catholics?" (319). That is, could it be a reflection of God's fidelity to the Jewish people as many religious Jews understand it? Cunningham is inclined to believe that the return of Jews to selfgovernance on the Land could constitute "covenantal restoration" but with the important caveat that this is possible only if peace is attained between Israelis and Palestinians (321). When that happens, the Jewish return will testify not only to God's presence in current events but also to how that restoration reflects the ultimate reign of God in eschatological time.

The "Curriculum for Dialogue about Israel-Palestine" in Part II contains an introductory essay ("Partners in Hope: Constructive Interreligious Dialogue through Text Study") intended to guide groups studying primary and secondary Christian, Jewish, Palestinian, and Israeli texts. The goal of that study is to encourage appreciation of the other's views even in the midst of disagreement. The texts include statements about the Land and State of Israel by the Church of Scotland, the Reform and Conservative denominations, Christian Zionists, Palestinian Church leaders, Israeli religious Zionists, and the ICCJ. This part provides the kind 
of practical advice and activity absent in exclusively academic or theological treatments of the subject, indicating that the book's editors intend the volume be used not only for reflection but also for nurturing cooperation and partnership.

That only one contributor is a native Israeli or Palestinian may not be an accident. It seems that the deep wounds of which Neuhaus speaks has imprisoned most of the Land's inhabitants and paralyzes them from moving forward. Victimhood too often dominates their consciousness, blocking them from humanizing the other and rendering constructive dialogue near-impossible. However, as the book demonstrates, Christians and Jews can model genuine dialogue characterized by mutual recognition and empathetic listening. In doing so, they contribute to the heavy lifting of peace-building, which is no small matter in political or in sacred history. 